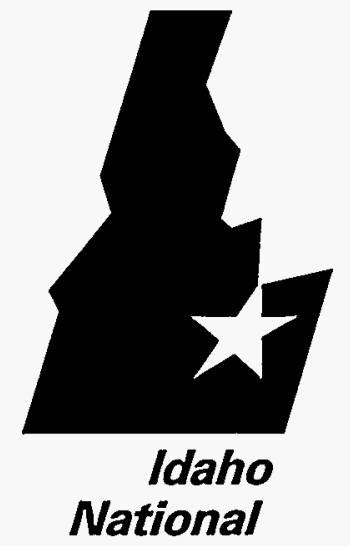

Engineering Laboratory
INEL-96/0017

January 1996

\section{Liquid Abrasive Pressure Pot Scoping Tests Report}

RECENED

FEB 23 BOS

OSTI
K. E. Archibald

Zu Lockheed
Idaho Technologies Company 



\title{
Liquid Abrasive Pressure Pot Scoping Tests Report
}

\author{
K. E. Archibald
}

Published January 1996

Idaho National Engineering Laboratory High Level Waste Engineering \& Project Management Lockheed Idaho Technologies Company Idaho Falls, Idaho 83415

Prepared for the

U.S. Department of Energy

Under DOE Idaho Operations Office

Contract DE-AC07-941D13223

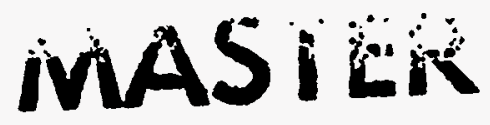

$H H$ 


$$
\therefore \quad \therefore
$$

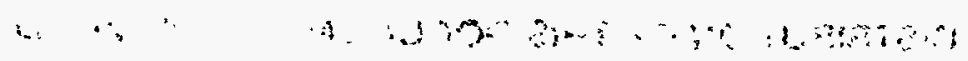




\section{CONTENTS}

Introduction $\ldots \ldots \ldots \ldots \ldots \ldots \ldots \ldots \ldots \ldots \ldots \ldots \ldots \ldots \ldots \ldots \ldots \ldots$

Objectives $\ldots \ldots \ldots \ldots \ldots \ldots \ldots \ldots \ldots \ldots \ldots \ldots \ldots \ldots \ldots \ldots \ldots \ldots \ldots \ldots \ldots \ldots$

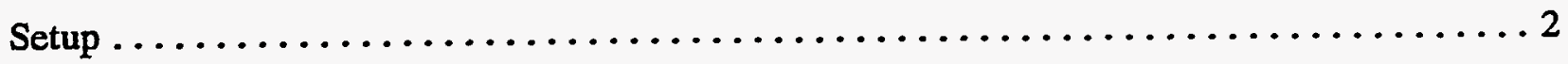

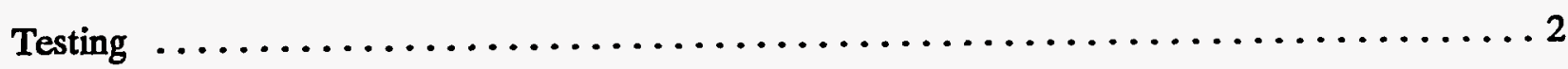

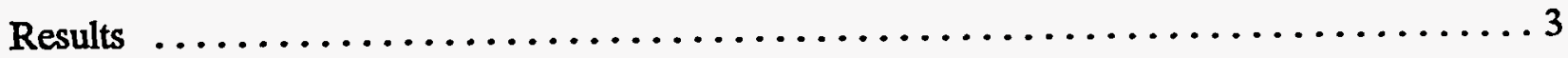

Recommendations $\ldots \ldots \ldots \ldots \ldots \ldots \ldots \ldots \ldots \ldots \ldots \ldots \ldots \ldots \ldots \ldots \ldots$

Conclusion $\ldots \ldots \ldots \ldots \ldots \ldots \ldots \ldots \ldots \ldots \ldots \ldots \ldots \ldots \ldots \ldots \ldots \ldots$

\section{TABLE}

1. LAPP Testing Results $\ldots \ldots \ldots \ldots \ldots \ldots \ldots \ldots \ldots \ldots \ldots \ldots \ldots \ldots \ldots \ldots \ldots \ldots$

\section{DISCLAIMER}

This report was prepared as an account of work sponsored by an agency of the United States Government. Neither the United States Government nor any agency thereof, nor any of their employees, makes any warranty, express or implied, or assumes any legal liability or responsibility for the accuracy, completeness, or usefulness of any information, apparatus, product, or process disclosed, or represents that its use would not infringe privately owned rights. Reference herein to any specific commercial product, process, or service by trade name, trademark, manufacturer, or otherwise does not necessarily constitute or imply its endorsement, recommendation, or favoring by the United States Government or any agency thereof. The views and opinions of authors expressed herein do not necessarily state or reflect those of the United States Government or any agency thereof. 



\section{Liquid Abrasive Pressure Pot Scoping Tests Report}

\section{Introduction}

The primary initiatives of the LITCO Decontamination Development group at the Idaho Chemical Process Plant (ICPP) are the development of methods to eliminate the use of sodium bearing decontamination chemicals and minimization of the amount of secondary waste generated during decontamination activities. In July of 1994, a Commerce Business Daily (CBD) announcement was issued by the INEL to determine commercial interest in the development of an in-situ liquid abrasive grit blasting system. As a result of the CBD announcement, Klieber \& Schulz issued an Expression of Interest letter which stated they would be interested in testing a prototype Liquid Abrasive Pressure Pot (LAPP). LITCO's Decontamination Development group and Kleiber \& Schulz entered into a Cooperative Research and Development Agreement (CRADA) in which the Decontamination Development group tested the prototype LAPP in a non-radioactive hot cell mockup.

\section{Objectives}

The objectives of this scoping test included:

1) Determine the ease of setup and operation of the system.

2) Determine the effectiveness of the LAPP for decontaminating various surfaces including tanks, piping and cell walls.

3) Determine the effectiveness of the vacuum recovery system in collecting the used abrasive and returning the abrasive into the blast pot for reuse.

4) Determine the effectiveness of various abrasives when used with the LAPP.

5) Determine the effectiveness of controlling the amount of airborne dust and particulate by using a small amount of liquid. 
6) Determine the amount of secondary waste generated.

7) Make recommendations to improve the LAPP for hot cell use.

\section{Setup}

The hot cell mockup was a $6^{\prime}$ wide $\times 11^{\prime}$ long $\times 6^{\prime}$ high room constructed of stainless steel which contained stainless vessels and piping arranged to simulate an actual hot cell. Stainless steel coupons with simulated fixed contamination (SIMCON) were attached with sealant in sets of three to the wall, pipe and tank surfaces inside the hot cell mockup.

The LAPP system has a foot print of $5^{\prime} \times 5^{\prime}$ and stands approximately $5^{\prime}$ tall. The main blasting system is on wheels and can be moved to the area where the blasting is performed. This system operates by placing abrasive with a small amount of water in the pressure vessel and then pressurizing it with air. This pressure closes off the top opening with a pop up valve. A valve at the bottom is then opened allowing the abrasive slurry to go through the hose to the blasting nozzle. A trigger on the nozzle is used to start the blasting. The preferred compressed air requirement for this system is $250 \mathrm{cfm}$ at a maximum pressure of $100 \mathrm{psi}$. The minimum air requirement for blasting is $165 \mathrm{cfm}$ at approximately $60 \mathrm{psi}$. The ICPP plant air did not meet the minimum air requirements to operate the system so an air compressor was used. The abrasive slurry used in this system can contain a variable percentage of water and grit depending how aggressive the slurry needs to be to clean the material.

The LAPP uses a recycling process to reduce the amount of liquid and solid waste generated. A vacuum system collects the used grit and water and returns it to be reused. The vacuum system can stand alone or can be placed over the main blasting system for easier reuse. The vacuum system, which stands $10^{\prime}$ tall, was placed to the side of the blasting system for these tests. A bucket was placed inside a drip pan under the vacuum to collect the used grit.

The LAPP system and vacuum were located outside of the mockup cell area while the slurry and vacuum hoses were routed inside.

\section{Testing}

The LAPP testing was started by using two $50 \mathrm{lb}$ bags of glass beads (Cataphote Inc. EGS, designation \#6) with water to the pressure pot, using a ratio of 
1.85 gal. of glass beads per .92 gal. of water (ratio 2 to 1 ) for the first bag. The second bag was added using a ratio of 4 to 1 glass beads to water. These were the least aggressive of the various abrasives available. A $1 / 2$ inch diameter air supply line was then connected from the blasting system to the air compressor. When the compressor was started and the blast lever was placed to the on position, the pop-up valve didn't respond. It was determined that a larger air supply line was needed and a 1 inch diameter air supply hose was used. The blast lever was then placed to the ON position and the pop-up valve sealed off the pressure vessel. Because of air compressor limitations, the maximum blast pressure obtained was 60 psi.

When the trigger on the blast nozzle was first pulled there was only a small amount of abrasive being discharged from the nozzle. The abrasive valve, which is located at the bottom of the blasting system, was adjusted so that more abrasive could be released. The system was used to blast a stain on the stainless steel floor of the mock-up until sufficient abrasive reached the nozzle. The coupons were then blasted at different distances, angles, and times to determine the overall cleaning efficiency and metal degradation. After the coupons had been blasted, the abrasive was vacuumed up from the floor. The vacuum was very effective and easy to use but the lack of wheels made it difficult to move to the correct area.

Operation of the LAPP system required a minimum of two people; one person to work the blasting nozzle and one to watch the gauges and control the equipment. The blasting nozzle was easily controlled with very little kick back when the trigger was pulled. The hoses would had to be manipulated to prevent a tripping hazard and entanglement around the vessels or piping.

\section{Results}

The entire LAPP system was very easy to operate. The system generated very little liquid waste and the only secondary waste generated were the blast beads.

The cleaning results from this test are depicted in Table 1. These results indicated that the LAPP system is very effective and is a fast method to use to decontaminate stainless steel. All of the coupons were blasted to a shiny finish. The only set of coupons that were not cleaned were the set of three that were located approximately 1 foot from a set that were being blasted. This set of coupons were used to determine the amount of over spray during blasting. These coupons were cleaned to small degree which would indicate that the system is still producing some cleaning at a radius of at least $1 \mathrm{ft}$.

The results from the EGS glass beads indicated that testing the more aggressive abrasives was not necessary as all coupons were below detectable limits. 
The total amount of beads collected after vacuuming was 13 pounds (used during 13 total minutes of blasting at $1 \mathrm{lb} / \mathrm{min}$ ). A small amount of glass beads were left on the inside of the vacuum but the majority of the beads remained in the blasting system despite operation of the system until no further abrasive exited the nozzle.

These probably could be flushed out using water when cleaning was needed or blasted out if the water ratio was increased during operation. The different ratios of water and grit didn't seem to effect the cleaning efficiency of the system.

During blasting there was a slight mist present but not enough to block the vision of the operator. The operator did indicate that he could feel the beads hitting him as they bounced off the wall. When blasting was complete the prefliters were weighted and checked to see how much grit or material had reached the filters. The results showed that the filters had only increased by a few grams. This indicated that the majority of the material and grit stayed inside the cell.

\section{TABLE 1 \\ LAPP Testing Results}

\begin{tabular}{|c|c|c|c|c|c|c|c|}
\hline Coupon \# & $\begin{array}{l}\text { Blasting } \\
\text { Angle } \\
\text { From } \\
\text { Surface }\end{array}$ & $\begin{array}{l}\text { Blasting } \\
\text { Time }\end{array}$ & $\begin{array}{l}\text { Blasting } \\
\text { Distance }\end{array}$ & $\begin{array}{c}\% \text { Cs } \\
\text { Before } \\
\text { (ug) }\end{array}$ & $\begin{array}{c}\% \mathrm{Zr} \\
\text { Before } \\
\text { (ug) }\end{array}$ & $\begin{array}{l}\% C s \\
\text { After } \\
\text { (ug) }\end{array}$ & $\begin{array}{c}\% \mathrm{Zr} \\
\text { After } \\
\text { (ug) }\end{array}$ \\
\hline PP-2-159 & $P$ & $\begin{array}{c}30 \\
\text { sec. }\end{array}$ & $6^{4}$ & 100 & 80 & BDL & BDL \\
\hline PP-2-013 & $P$ & $\begin{array}{c}30 \\
\text { sec. }\end{array}$ & $6^{\prime \prime}$ & 100 & 84 & BDL & BDL \\
\hline PP-2-007 & $P$ & $\begin{array}{c}30 \\
\text { sec. }\end{array}$ & $6^{\prime \prime}$ & 100 & 205 & BDL & BDL \\
\hline PP-2-014 & $P$ & $\begin{array}{c}30 \\
\text { sec. }\end{array}$ & $18^{4}$ & 101 & 81 & BDL & BDL \\
\hline PP-2-079 & P. & $\begin{array}{c}30 \\
\text { sec. }\end{array}$ & $18^{4}$ & 102 & 56 & BDL & BDL \\
\hline PP-2-115 & $P$ & $\begin{array}{c}30 \\
\text { sec. }\end{array}$ & $18^{\prime \prime}$ & 103 & 46 & BDL & BDL \\
\hline PP-2-002 & 45 & $\begin{array}{c}30 \\
\text { sec. }\end{array}$ & $6^{\prime \prime}$ & 104 & 144 & BDL & BDL \\
\hline
\end{tabular}




\begin{tabular}{|c|c|c|c|c|c|c|c|}
\hline Coupon \# & $\begin{array}{l}\text { Blasting } \\
\text { Angle } \\
\text { From } \\
\text { Surface }\end{array}$ & $\begin{array}{l}\text { Blasting } \\
\text { Time }\end{array}$ & $\begin{array}{l}\text { Blasting } \\
\text { Distance }\end{array}$ & $\begin{array}{c}\text { \%Cs } \\
\text { Before } \\
\text { (ug) }\end{array}$ & $\begin{array}{c}\% Z r \\
\text { Before } \\
\text { (ug) }\end{array}$ & $\begin{array}{l}\% \text { Cs } \\
\text { After } \\
\text { (ug) }\end{array}$ & $\begin{array}{l}\% \text { Zr } \\
\text { After } \\
\text { (ug) }\end{array}$ \\
\hline PP-2-026 & 45 & $\begin{array}{r}30 \\
\text { sec. }\end{array}$ & $6^{\prime \prime}$ & 105 & 68 & BDL & BDL \\
\hline PP-2-011 & 45 & $\begin{array}{c}30 \\
\text { sec. }\end{array}$ & $6^{\prime \prime}$ & 106 & 101 & $\mathrm{BDL}$ & BDL \\
\hline PP-2-032 & $P$ & $\begin{array}{c}30 \\
\text { sec. }\end{array}$ & $36^{\prime \prime}$ & 109 & 74 & BDL & BDL \\
\hline PP-2-130 & $P$ & $\begin{array}{c}30 \\
\text { sec. }\end{array}$ & $36^{\prime \prime}$ & 110 & 140 & BDL & BDL \\
\hline PP-2-041 & $\mathbf{P}$ & $\begin{array}{c}30 \\
\text { sec. }\end{array}$ & $36^{\prime \prime}$ & 110 & 59 & BDL & BDL \\
\hline PP-2-008 & 30 & $\begin{array}{c}30 \\
\text { sec. }\end{array}$ & $6^{4}$ & 113 & 57 & BDL & BDL \\
\hline PP-2-102 & 30 & $\begin{array}{c}30 \\
\text { sec. }\end{array}$ & $6^{4}$ & 113 & 85 & BDL & BDL \\
\hline PP-2-048 & 30 & $\begin{array}{c}30 \\
\text { sec. }\end{array}$ & $6^{\prime \prime}$ & 114 & 84 & BDL & BDL \\
\hline PP-2-121 & $P$ & $\begin{array}{c}10 \\
\text { sec. }\end{array}$ & $12^{\prime \prime}$ & 115 & 61 & $\mathrm{BDL}$ & BDL \\
\hline PP-2-001 & $P$ & $\begin{array}{c}10 \\
\text { sec. }\end{array}$ & $12^{\mu}$ & 116 & 92 & BDL & BDL \\
\hline PP-2-125 & $P$ & $\begin{array}{c}10 \\
\text { sec. }\end{array}$ & $12^{\prime \prime}$ & 116 & 58 & BDL & BDL \\
\hline PP-2-036 & $P$ & $\begin{array}{r}30 \\
\text { sec. }\end{array}$ & $12^{\mu}$ & 117 & 143 & BDL & BDL \\
\hline PP-2-157 & $\mathbf{P}$ & $\begin{array}{r}30 \\
\text { sec. }\end{array}$ & $12^{\mu}$ & 120 & 100 & BDL & BDL \\
\hline PP-2-018 & $P$ & $\begin{array}{c}30 \\
\text { sec. }\end{array}$ & $12^{4}$ & 122 & 127 & BDL & BDL \\
\hline PP-2-114 & $P$ & $1 \mathrm{~min}$. & $12^{\prime \prime}$ & 123 & 49 & $\mathrm{BDL}$ & $\mathrm{BDL}$ \\
\hline PP-2-086 & $P$ & $1 \mathrm{~min}$. & $12^{\prime \prime}$ & 124 & 58 & $\mathrm{BDL}$ & $\mathrm{BDL}$ \\
\hline
\end{tabular}




\begin{tabular}{|c|c|c|c|c|c|c|c|}
\hline Coupon \# & $\begin{array}{c}\text { Blasting } \\
\text { Angle } \\
\text { From } \\
\text { Surface }\end{array}$ & $\begin{array}{c}\text { Blasting } \\
\text { Time }\end{array}$ & $\begin{array}{c}\text { Blasting } \\
\text { Distance }\end{array}$ & $\begin{array}{c}\% \mathrm{Cs} \\
\text { Before } \\
\text { (ug) }\end{array}$ & $\begin{array}{c}\% \mathrm{Zr} \\
\text { Before } \\
\text { (ug) }\end{array}$ & $\begin{array}{c}\% \mathrm{Cs} \\
\text { After } \\
\text { (ug) }\end{array}$ & $\begin{array}{c}\% \mathrm{zr} \\
\text { After } \\
\text { (ug) }\end{array}$ \\
\hline PP-2-080 & $\mathrm{P}$ & $1 \mathrm{~min}$ & $12^{\mu}$ & 127 & 81 & $\mathrm{BDL}$ & $\mathrm{BDL}$ \\
\hline $\begin{array}{c}\mathrm{PP}-2-021 \\
\text { (ns) }\end{array}$ & $\mathrm{n} / \mathrm{a}$ & $\mathrm{n} / \mathrm{a}$ & $\mathrm{n} / \mathrm{a}$ & 132 & 153 & 40 & 120 \\
\hline $\begin{array}{c}\text { PP-2-087 } \\
\text { (ns) }\end{array}$ & $\mathrm{n} / \mathrm{a}$ & $\mathrm{n} / \mathrm{a}$ & $\mathrm{n} / \mathrm{a}$ & 132 & 65 & 50 & 40 \\
\hline $\begin{array}{c}\text { PP-2-124 } \\
\text { (ns) }\end{array}$ & $\mathrm{n} / \mathrm{a}$ & $\mathrm{n} / \mathrm{a}$ & $\mathrm{n} / \mathrm{a}$ & 132 & 113 & 70 & 80 \\
\hline
\end{tabular}

$\mathrm{BDL}=$ Below detectable limits.

(ns) $=$ Not sprayed

$P=P e r p e n d i c u l a r$ from the surface.

\section{Recommendations}

The following are recommendations for improvements to the LAPP system to allow it to be used at its full potential in a hot cell environment.

\section{A. Pressure Pot:}

Air Flow Regulator - The current system needs a separate air flow regulator to indicate the amount of flow going to the blast system. Incorporation of a separate air flow regulator would be a great benefit when using this system in a cell since not all air supply lines have air flow regulators.

Pressure Gauge - The pressure gauge located on the system should indicate a minimum and maximum pressure range in psi. The incorporation of this type of gauge would help determine the proper pressure when operating the system.

Air Flow - Redesign of the system to operate at lower air flows is needed. The current flow requirements of the system are to large for standard plant air.

Blasting System - The system is difficult to move with one person. A smaller system may be more practical for in cell use. The smaller unit would require less 
air flow to operate and the hoses and nozzle would be smaller which would making it easier for an operator to use.

Shroud - The shroud that is located on the bottom of the vacuum is small. When transferring used abrasives from the vacuum to the blast system, the shroud would have to cover the entire.top of the blast system to ensure all the abrasivès and water were contained during the transfer.

Material - The system will have to be decontaminated after it has been used in a contaminated environment. To make it easier to decontaminate, the system should be constructed of non-painted stainless steel.

Abrasive Ball Valve - The ball valve.should have some kind of labeling which would tell the operator if the valve is closed or to what extent it is open.

Abrasive Removal - The removal of unused abrasive from the pressure pot is difficult. To make it easier to remove there needs to be a easier way to get inside the pressure pot.

Water Level Indicator - The system needs a visible water level indicator to tell the operator when the system is full.

Cover - The top of the blasting system needs a removable cover to prevent the spread of contamination when the system is started or stopped.

Blast Hose - The blast hose needs a hard connection to the pressure pot to prevent leaking.

\section{B. Vacuum:}

Wheels - The vacuum should be made more mobile by adding wheels with locking:devices.

Material - The vacuum system should be constructed of stainless steel where possible. This will make it easier to decontaminate after it has been used.

Filters - The filter should be easier to replace. All filters must be DOP tested before they are used. The system should include a gauge to tell the operator when the filter needs to be changed.

Level Indicator - The vacuum needs a level indicator to tell the operator whether it is empty or full. 
Lever - The closing mechanism on the bottom of the vacuum doesn't seal completely. When the vacuum is not located over the blasting system, it must be able to hold all the abrasive in the vacuum even if the air supply is shut off.

\section{Conclusion}

The Lapp system is a very effective and fast cleaning/decontamination method. The system could be used for industrial cleaning without any modifications. However, improvements to system would have to be made to allow it to be used at its full potential in radioactively contaminated areas. 